\title{
Influence of Autochthonous and Commercial Yeast Strains on Fermentation and Quality of Wines Produced from Vranec and Cabernet Sauvignon Grape Varieties from Tikveš Wine-Growing Region, Republic of North Macedonia
}

\author{
Fidanka Ilieva $^{1}$, Kire Petrov ${ }^{2}$, Sanja Kostadinović Veličkovska ${ }^{1}$ (D), Natasa Gunova ${ }^{1}$, Violeta Dimovska ${ }^{1}$, \\ João Miguel F. Rocha ${ }^{3}$ (D) and Tuba Esatbeyoglu $4, *$ (D)
}

1 Department for Food Technology, Faculty of Agriculture, University "Goce Delčev", 2000 Štip, North Macedonia; fidanka.ilieva@ugd.edu.mk (F.I.); sanja.kostadinovik@ugd.edu.mk (S.K.V.); natasagunova@gmail.com (N.G.); violeta.dimovska@ugd.edu.mk (V.D.)

2 Tikveš Winery, Street: November 29. Number 5, 1430 Kavadarci, North Macedonia; kire.petrov@tikves.com.mk

3 REQUIMTE-Chemistry and Technology Network, Green Chemistry Laboratory (LAQV), Department of Chemistry and Biochemistry, Faculty of Sciences from University of Porto (FCUP), Rua do Campo Alegre s/n,

check for updates

Citation: Ilieva, F.; Petrov, K.; Veličkovska, S.K.; Gunova, N.; Dimovska, V.; Rocha, J.M.F.; Esatbeyoglu, T. Influence of Autochthonous and Commercial Yeast Strains on Fermentation and Quality of Wines Produced from Vranec and Cabernet Sauvignon Grape Varieties from Tikveš Wine-Growing Region, Republic of North Macedonia. Appl. Sci. 2021, 11, 6135. https://doi.org/10.3390/ app11136135

Academic Editor: Monica Gallo

Received: 21 May 2021

Accepted: 28 June 2021

Published: 1 July 2021

Publisher's Note: MDPI stays neutral with regard to jurisdictional claims in published maps and institutional affiliations.

Copyright: (c) 2021 by the authors Licensee MDPI, Basel, Switzerland. This article is an open access article distributed under the terms and conditions of the Creative Commons Attribution (CC BY) license (https:/ / creativecommons.org/licenses/by/ $4.0 /)$.
P-4169-007 Porto, Portugal; jrocha@sourdomics.com

4 Institute of Food Science and Human Nutrition, Gottfried Wilhelm Leibniz University Hannover, Am Kleinen Felde 30, 30167 Hannover, Germany

* Correspondence: esatbeyoglu@lw.uni-hannover.de; Tel.: +49-5117625589

\begin{abstract}
Two autochthonous yeast strains called F-8 and F-78 (isolated and selected from the Tikveš wine-producing region) were inoculated in wine musts from Vranec and Cabernet Sauvignon grape varieties. The fermentation process and quality of the produced wines were compared to the wines produced from the same grape varieties, but with a commercial yeast strain (D-80). The fermentation process was undertaken at $23-25^{\circ} \mathrm{C}$ for 16 days. The highest alcohol content was detected in Vranec and Cabernet Sauvignon wines fermented with autochthonous F-8 yeast strain. Conversely, Vranec wine fermented by the F-78 yeast strain contained the lowest alcohol content $(14.11 \%)$. The low sugar amount $(2-3 \mathrm{~g} / \mathrm{L})$ in both grape varieties is indicated the production of dry wines. The total amount of phenolic compounds was significantly higher in Vranec wines. Unlike the alcohol content, Vranec wine produced by commercial yeast strain D-80 indicated the highest concentration of total phenolic compounds (1450 mg/L) and total anthocyanins (572 mg/L), while the lowest concentrations were observed in wine fermented by autochthonous yeast strain F-78 $(1612 \mathrm{mg} / \mathrm{L}$ and $470 \mathrm{mg} / \mathrm{L}$, respectively). The maximum color intensity was measured in the Vranec wine fermented by autochthonous yeast strain F-8, while wines from Cabernet Sauvignon grape variety fermented with the same yeast strain F-8 and commercial yeast strain D-80 had comparable values in terms of color intensity.
\end{abstract}

Keywords: Saccharomyces cerevisiae; autochthonous yeast strains; commercial yeast strains; fermentation; wine quality; Vranec wines; Cabernet Sauvignon wines; total phenolic compounds; total anthocyanins; color

\section{Introduction}

Nowadays, selected pure cultures of wine yeasts are mainly used in winemaking, which has led to a significant improvement in wine technology and respective final quality, because of multiple benefits such as the ability to undertake a quick and effective fermentation of grape juice or must with high sugar concentration; resistibility to high levels of ethanol $\left(\mathrm{C}_{2} \mathrm{H}_{6} \mathrm{O}\right)$ and sulfur dioxide $\left(\mathrm{SO}_{2}\right)$; and resistance to high temperatures during fermentation [1]. 
Indeed, the increasing usage of traded selected yeasts for winemaking leads inevitably to a loss of the autochthonous yeast populations naturally present in regional grapes and, consequently, drives to the potential loss of genetic diversity and heritage. Largely, the specificities, authenticity, uniqueness and, most importantly, the quality characteristics of the wine are dependent on the natural microbiota found in the grapes of each viticulture region [2] and, of course, the quality of the grapes by itself, which deeply depends on the soil and climate conditions of the geographic region and the employed viticulture techniques, which also determine per se the type of microbiota present therein.

Over the last few years, increasing interest among scientists and winemakers has been observed in exploiting autochthonous yeast strains. After isolation and the selection of yeast strains with good phenotype and technological characteristics, they can be further employed in winemaking processes with high potential to be successful. Such a trend can be very important toward ameliorating the microbial biodiversity in the selected region and contributing to enriching the biological heritage, which is of great importance, in a highly competitive market, for the winery industry chasing for wine appellation and production of wines with unique/differentiated flavors and aromas [3].

Comparison of the main communities of cultivable yeast species and strains between two different neighboring Vitis ecosystems suggested that specific (yet unknown) characteristics of different symbiotic Vitis species may contribute to the assembly of specific communities of biologically compatible yeast strains from a given number of species. In turn, the growth dynamics of these yeast populations during spontaneous fermentation can be translated into specific organoleptic and sensory traits of the final wines, depending on each variety of grape [4]. In addition, the microbial dynamics of alcoholic fermentation significantly affect the extraction of anthocyanins from grape skins and tannins from grape seeds, which will further influence, in cascade, the overall bitterness and astringency of the red wines [5]. Moreover, different maceration techniques, namely enzyme treatment, cold-soaking, and post-maceration as well as the combination of cold with post-maceration, influence the extraction process and the subsequent level of anthocyanins and tannins in wines [6]. The environment of wine fermentation has a great impact on the extraction and retention of tannins and other phenolic compounds from the red grape skins and seeds $[7,8]$. An adequate selection of the indigenous and commercial yeast strains combined with the use of enological tannins containing a mixture of phenolic compounds was employed to drive the transformation of the grape anthocyanins into certain derivatives, some of which are more stable from a chemical standpoint $[9,10]$. On the other hand, anthocyanins are the main compounds present in young red wines, being responsible for their intense red color. These pigments are mainly located in the grape skins and their extractability during winemaking depends on many factors such as their concentration in cell vacuoles and their interaction with the cell-wall polysaccharides, thus further affecting their stability and concentration in the must [11]. The biochemical pathways of formation in red wine are composed of a great variety of pyranoanthocyanin structures, namely carboxypyranoanthocyanins, methylpyranoanthocyanins, pyranoanthocyanin-flavanols, pyranoanthocyanin-phenols, portisins, oxovitisins, and pyranoanthocyanin dimers that can significantly influence the color and the overall taste of red wines as well as the monomeric anthocyanins and their color expression [12-14].

The main aim of the current research effort was to attain the estimation of the best winemaking procedure and the most favorable yeast strains toward the production of high-quality premium wines from Vranec and Cabernet Sauvignon grape variety from the "Tikveš" wine-growing region. The wines from both grape varieties were fermented by two autochthonous yeast strains, F-8 and F-78, and a commercial yeast strain, D-80; all strains belong to the Saccharomyces cerevisiae species. The dynamics of alcoholic fermentations were ascertained and the quality of the produced wines estimated. The enological parameters under scrutiny were the percentage of alcohol, sugar content, total and volatile organic acids, and $\mathrm{pH}$ of the wines. Furthermore, total phenolic content, total anthocyanins and color intensity (IC) were also determined to estimate the best winemaking procedures to 
yield in such a high-quality premium wine from Vranec and Cabernet Sauvignon grape variety from the "Tikveš" wine-growing region of the Republic of North Macedonia (MK).

\section{Materials and Methods}

\subsection{Grapes from Vranec and Cabernet Sauvignon Variety for Winemaking and Chemicals}

Grapes were provided by local farmers from the Kavadarci wine-growing region (Kavadarci, North Macedonia). Grapes from Vranec (Tikveš, Kavadarci, North Macedonia) and Cabernet Sauvignon (Tikveš, Kavadarci, North Macedonia) varieties for this study were harvested in September 2016 and 2017 in the area of "Crveni Bregovi", located in the "Tikveš" wine-growing region (Kavadarci North Macedonia). The grapes were harvested at their optimum time of maturation. Samples of undamaged grapes were taken at random for further analyses, placed in sterile bags (ISOLAB, Eschau, Germany) and kept in a refrigerator (Beko, Istanbul, Turkey) at $5{ }^{\circ} \mathrm{C}$. All grape samples were stored for five days.

Prior to the analyses, the grapes were selected manually by tossing out rotten or peculiar-looking grapes. After washing and removing the steams, the grapes were crushed to release the must. The total sugar content was determined according to the methodology described by the International Standard Method OIV-AS2-02-SUCREF (2007) [15], while titratable acidity and $\mathrm{pH}$ were determined by the International Standard Method OIV-AS313-01-ACITOT (2009) [16]. These assays in grapes were performed in two replicates for each harvested year (two replicates for 2016 and two replicates for 2017) and the chemical parameters were determined in duplicate. All chemicals for these grape analyses were purchased from Sigma-Aldrich (Seelze, Germany) and Merck (Darmstadt, Germany), and were of analytical reagent grade.

\subsection{Isolation, Selection, and Identification of Autochthonous Yeast Strains F-8 and F-78 from the Tikveš Wine-Growing Region}

The procedure of isolation and selection of endogenous yeast strains F-8 and F-78 was previously described by the research group of Ilieva $(2016,2017,2019)$ [17-19]. Briefly, spontaneous fermentations of 10 different lots Vranec and five different lots of Cabernet Sauvignon from different micro-regions were held. After destemming, crushing, and addition of sulfuric acid (dosage $20 \mathrm{mg} / \mathrm{kg}, 5 \%$ sulfuric acid), the spontaneous fermentation took place at $25-28{ }^{\circ} \mathrm{C}$ in polyethylene terephthalate (PET) vessels (Ilsen $\mathrm{GmbH}$, Hövelhof, Germany). From the experimental trials, pure yeast cultures were isolated according to the Koch method (Bambalov et al., 2000) [20]. The microbial isolation was executed from single colonies, cultivated in test tubes with nutrient agar (NA) culture medium with sterilized grape juice in a thermostat in water bath at $25^{\circ} \mathrm{C}$. Subsequently, the isolated and purified strains were subjected to a three-stage selection based on their fermentation ability.

Moreover, the fermentation activity of the selected pure yeast strains F-8 and F-78 was evaluated in sterilized liquid grape juice. In sterilized sample tubes with $10 \mathrm{~mL}$ of the aforementioned juice each yeast culture was inoculated, previously activated during 72-h using a sterile inoculating loop. The assays were carried out in a thermostatic water bath at $25^{\circ} \mathrm{C}$, and the evolution of the alcoholic fermentation was checked with a refractometer (Krüss, Hamburg, Germany). The F-8 and F-78 autochthonous yeast strains were selected based on their superior technological characteristics. Afterward, $2 \mathrm{~mL}$ of liquid inoculums were inoculated in the prepared sterile tap glass bottles $(0.5 \mathrm{~L})$ for the evaluation of their fermentation activity. The bottles were closed with fermentation caps and the course of the fermentation was monitored by the evaluation of the levels of residual sugar. The first determination of sugar fermentation capacity of the selected yeasts was determined in Petri dishes by pouring each strain in a mixture of $0.6 \%(w / v)$ yeast extract solution with the addition of $0.2 \%(w / v)$ of each of the following carbohydrates: glucose, fructose, galactose, maltose, saccharose, and raffinose (in this last case, in a concentration of $0.4 \%, w / v$ ).

For the second and final confirmation of the ability of the strains to assimilate carbon sources, the BioMerieux API 20C AUX kit (Merck, Darmstadt, Germany) was used (Ilieva et al., 2019) [19]. Biomass from pure fresh colonies was suspended in a saline solu- 
tion $(0.1 \%, w / v)$. After first homogenization, $0.1 \mathrm{~mL}$ of the previous suspension was added to the control mixture $(\mathrm{C})$ from the kit, which contains nitrogen derivatives, vitamins, and growth factors but in the absence of carbohydrate sources. After a second homogenization, the mixture was pipetted into the wells of the API $20 \mathrm{C}$ strip and incubated at $25^{\circ} \mathrm{C}$. At the incubation times of 24,48 , and $72 \mathrm{~h}$, the turbidity of the liquid in the wells was compared against the control (C) to verify the capacity to metabolize the different carbon sources. Based on these results, the identification of the species level of the yeast strains was possible to achieve [19].

\subsection{Inoculation of Autochthonous and Commercial Yeast Strains and Monitoring of the Alcoholic Fermentation toward the Production of Vranec and Cabernet Sauvignon Wines}

Vranec and Cabernet Sauvignon grapes were equally allocated to the lots, in order to make similar fermentation conditions. The grapes were collected in stillness still large and sturdy containers (40.64 cm deep and $50.80 \mathrm{~cm}$ wide). One lot (one replicate) per type of grape per yeast strain gave rise to six lots (two grapes $x$ three yeast strains). Twenty kilograms of destemmed grapes were crushed with a manual crusher (GW Kent, Ypsilanti, USA), and $17.4 \mathrm{~kg}$ of the must was produced ( $\left.72 \%, \mathrm{w}_{\text {must }} / \mathrm{w}_{\text {grapes }}\right)$. Furthermore, $20 \mathrm{mg} / \mathrm{kg}$ of $\mathrm{SO}_{2}$ was added. Two hours after crushing, the two isolated endogenous yeast strains (F-8 and F-78) and the commercial yeast strain Saccharomyces cerevisiae D-80 (Lallemand Inc., Vienna, Austria) were inoculated in a dosage of 0.2 ginoculum $/ \mathrm{L}$ for each lot and each variety. The maceration time for all trials lasted 16 days. Alcoholic fermentation was controlled in a fermentation chamber at the temperature of $23-25^{\circ} \mathrm{C}$.

The six experimental wines (combination of two types of wine grapes and three types of yeast strains) were produced from Vranec and Cabernet Sauvignon grape varieties by application of autochthonous yeast (F-7 and F-78) and commercial yeast (D-80) strains (Table 1). Six experimental wines were produced from Vranec and Cabernet Sauvignon grapes from 2016 and 2017 harvesting years, respectively.

Table 1. Experimental design for the wines produced with Vranec and Cabernet Sauvignon grape varieties and fermented by autochthonous and commercial yeast strains.

\begin{tabular}{lccc}
\hline Wine Designation & Grape Variety & Yeast Strain & Oenological Parameters \\
\hline V1 & Vranec & F-8 & Alcohol (ethanol) \\
V2 & Vranec & F-78 & Total reducing sugars * \\
V3 & Vranec & D-80 & Volatile acidity (VA) \\
CS1 & Cabernet Sauvignon & F-8 & Color intensity (IC) \\
CS2 & Cabernet Sauvignon & F-78 & Total monomeric anthocyanins \\
CS3 & Cabernet Sauvignon & D-80 & Total phenolic compounds \\
\hline * Note: In addition to the pH values, the grapes were subjected to the determination of total reducing sugars \\
and TA.
\end{tabular}

\subsection{Determination of Oenological Parameters in Trial Wines}

Determination of the amount of alcohol was performed ebuliometrically by a DujardinSalleron ebulliometer (GW Kent, Ypsilanti, USA) method (Zoecklein et al., 1995) [21], and for the determination of total reducing sugars, the Luff-Schoorl method (ISI 28-1e: Determination of Reducing Sugar, DE by Luff-Schoorl's method) was used and the results expressed as g/L [22]. Quantification of titratable (TA) and volatile (VA) organic acidity in wines was performed according to the methodologies described by Ilieva et al. (2017) [19], and both are expressed as g/L. Determination of color intensity (IC) (as absorbance units, a.u.) was performed spectrophotometrically by measuring the absorbance of the wines at $420 \mathrm{~nm}$ (yellow color), $520 \mathrm{~nm}$ (red color), and $620 \mathrm{~nm}$ (blue color) with a UV spectrophotometer (Shimadzu 1800, Shimadzu Corporation, Kyoto, Japan). Determination of total monomeric anthocyanins was performed by the AOAC International Method (Official Method 2005.02: Total Monomeric Anthocyanin Pigment Content of Fruit Juices, Beverages, Natural Colorants, and Wines) and expressed as mg/L [23]. Determination of 
total phenolic content was performed by the AOAC International Method (AOAC SMPR 2015.009: Estimation of Total Phenolic Content Using the Folin-Ciocalteu Assay, 2015) and expressed as $\mathrm{mg} / \mathrm{L}$ [24]. The $\mathrm{pH}$ values of the wines were determined by the International Standard Method according to OIV-MA-AS313-01 [25].

The oenological parameters were determined in two replicates for each harvested year and the analytical measurements were performed in duplicate $(2 \times 2=4$, every measurement was obtained as a mean value of two replications of each harvested year). All chemicals in these experiments were purchased from Millipore Sigma (Burlington, VT, USA) and Merck (Darmstadt, Germany), and were of analytical reagent grade.

\subsection{Statistical Analysis}

The experimental results of the produced wines were subject to independent two-way analysis of variance (ANOVA) to examine the impact of each fixed factor (i.e., the selected yeast strains $(n=3)$ and the selected grapes $(n=2))$, on the dependent variables (i.e., the content of total anthocyanins, total phenolic compounds, total reducing sugars, $\mathrm{pH}$, titratable and volatile acidities). Additional two-way ANOVA (analysis of variance) was used for determination of differences in dynamics of alcohol fermentation for Vranec wines (over 3-7 days) and Cabernet Sauvignon wines (over 3-9 days). The level of significant differences of the mean values ( $p$-value) used was $5 \%$ for all the performed two-way ANOVA F- and Tukey's tests. When the F-tests resulted in significant differences, the mean values were further subjected to Tukey's-HSD post-doc tests for a comparison of the mean differences between groups of the independent variables (i.e., the type of yeast strain and the type of wine grape) could be undertaken. The IBM SPSS Statistics v.16.0 software (IBM Corporation, Chicago, IL, USA) was used for the statistical analyses.

\section{Results}

During the fermentation processes, the sugar content of the juice of ripe Vranec and Cabernet Sauvignon grapes was $247 \mathrm{~g} / \mathrm{L}$ and $236 \mathrm{~g} / \mathrm{L}$, respectively. Titratable acidity (TA) was in the range of 6.7-7.1 g/L, while $\mathrm{pH}$ values for grapes from the Vranec and Cabernet Sauvignon grape variety were 3.54 and 3.40, respectively. Data were measured before fermentation and presented as mean values of two replicates from each harvested year (2016 and 2017, respectively) (Table 2).

Table 2. Sugar content, titratable acidity, and $\mathrm{pH}$ values of grapes from Vranec and Cabernet Sauvignon for vintage years 2016 and 2017.

\begin{tabular}{ccccc}
\hline Grape Variety & Vintage Year & Sugar Content (g/L) & Titratable Acidity (TA) (g/L) & pH \\
\hline Vranec & 2016 & 245 & 234 & 3.51 \\
Vranec & 2016 & 249 & 238 & 3.54 \\
Cabernet Sauvignon & 2017 & 246 & 235 & 3.41 \\
Cabernet Sauvignon & 2017 & 248 & 237 & 3.40 \\
\hline
\end{tabular}

3.1. Dynamics of the Alcoholic Fermentation throughout Time to Produce Wines from Vranec and Cabernet Sauvignon Grape Varieties

The autochthonous and commercial yeast strains, belonging to the species of Saccharomyces cerevisiae, clearly demonstrated different dynamics of alcoholic fermentation and different content of dry-matter for Vranec wines. As seen in Figure 1, the application of autochthonous yeast strain F-78 indicated a faster and sharper decrease in total sugar content in the wines from the Vranec grape variety, while application of commercial yeast D-80 led to a slower decrease of total sugars in the wines from the same grape variety. The differences in the shape of the curves for the three Vranec wines are especially noticeable from the fifth day to the eighth day of the alcoholic fermentation. 


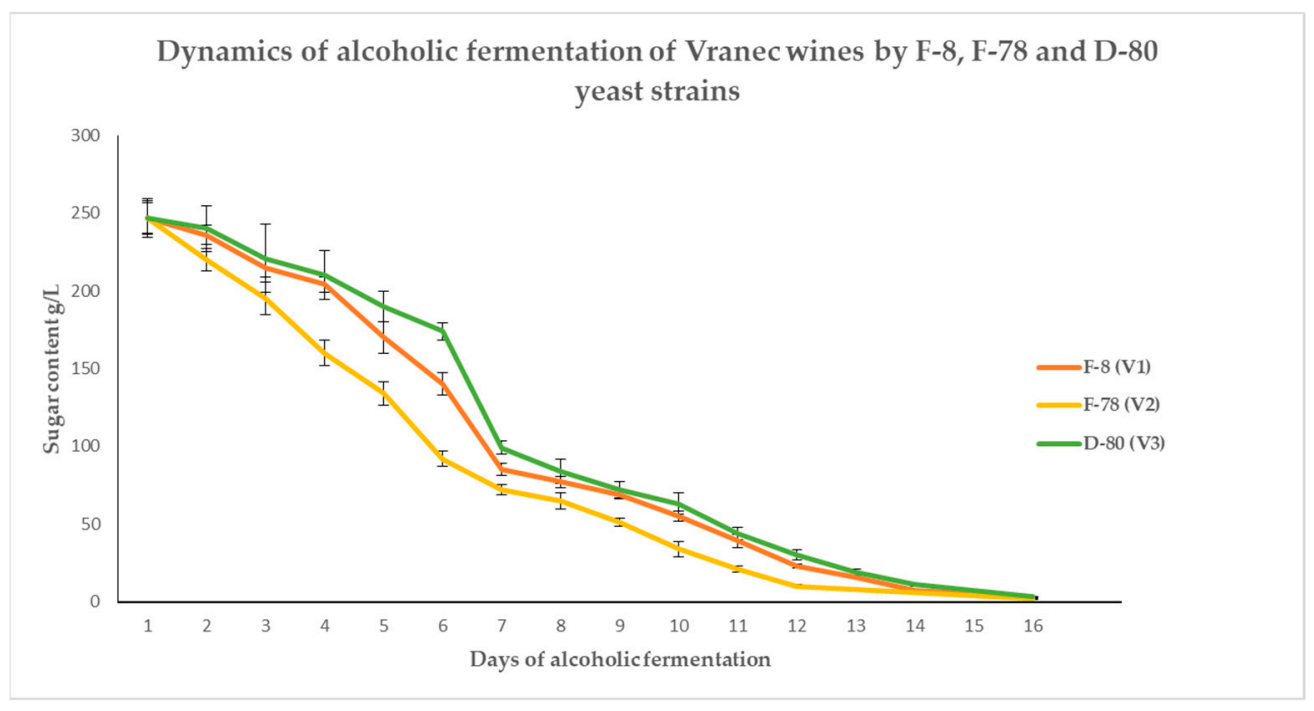

Figure 1. Dynamics of alcoholic fermentation of Vranec wines produced by autochthonous and commercial yeast strains, obtained by screening of the total amount of reducing sugars. The results refer to the mean values and standard deviations (mean \pm STDV), expressed as g/L. Mean \pm STDV were calculated from one replicate of each fermentation type (see Table 1) and four analytical measurements. Wine type abbreviations are defined in Table 1.

At the end of alcoholic fermentation (16th day), the amount of residual sugar was in the range of 2-3 g/L, thus leading to the production of dry-wines, while the percentage of alcohol was in the range of 13.97-14.68\% (vol.). Moreover, the results depicted in Figure 1 indicate that likewise, the commercial yeast (D-80) and the autochthonous (F-8 and F-78) yeasts also finished the alcoholic fermentation with similar amounts of total residual sugars.

The dynamics of the alcoholic fermentation of wines produced from the Cabernet Sauvignon grape variety by application of the same yeast strains (F-8, F-78, and D-80) are illustrated in Figure 2.

Dynamics of alcoholic fermentation of Cabernet Sauvignon wines by F$8, \mathrm{~F}-78$ and $\mathrm{D}-80$ yeast strains

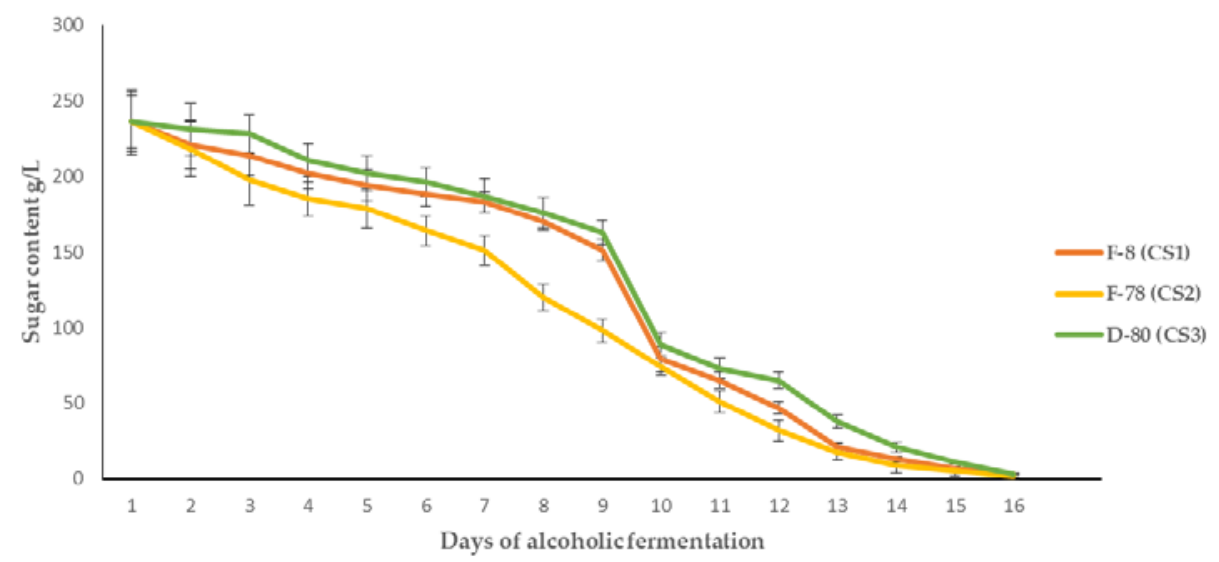

Figure 2. Dynamics of the alcoholic fermentation of Cabernet Sauvignon wines produced by autochthonous and commercial yeast strains through the screening of the total amount of reducing sugars. The results refer to the mean values and standard deviations (mean \pm STDV), expressed as $\mathrm{g} / \mathrm{L}$. Mean \pm STDV were calculated from one replicate of each fermentation type (see Table 1) and four analytical measurements. Wine type abbreviations are defined in Table 1. 
As seen in Figure 2, the shapes of the curves were slightly different in comparison to Vranec wines (Figure 1). The decrease of the sugar content in the Cabernet Sauvignon wine fermented by F-78 (wine CS2) was smoother while wines CS1 and CS3 (wines fermented with F-8 and D-80, respectively) had similar shape of curves with a sharper decrease in total sugar content from the 9th to 11th days of fermentation when compared to the previous days of fermentation. Although there was a smoother decrease, the autochthonous yeast strains F-8 and F-78 pointed toward a similar shape of decrease in comparison to commercial yeast strain D-80 in the total sugar contents throughout time in the wines from the Cabernet Sauvignon grape variety (Figure 2). The alcohol content for Cabernet Sauvignon wines were in the range of $14.11-14.96 \%$ (vol.). Furthermore, the amount of total residual sugars was less than $3 \mathrm{~g} / \mathrm{L}$. Statistical analysis (two-way ANOVA) indicated that the fermentation rate of indigenous yeast strain F-78 was superior for the musts (especially over 3-7 days for Vranec wines and 3-9 days for Cabernet Sauvignon wines) in comparison to the fermentation rate of indigenous F-8 and commercial D-80 yeast strains (Table 3).

Table 3. Two-way ANOVA statistical analysis for fermentation of the must from Vranec (from the 3rd to 7th days) and Cabernet Sauvignon (from the 3rd to 9th days) grapes.

\begin{tabular}{|c|c|c|c|c|c|}
\hline $\begin{array}{c}\text { Days of } \\
\text { Fermentation }\end{array}$ & Type of Yeast & $\begin{array}{c}\text { Content of Sugar } \\
\text { in Must from } \\
\text { Vranec Grapes } \\
(\mathrm{g} / \mathrm{L})\end{array}$ & $\begin{array}{c}\text { Days of } \\
\text { Fermentation }\end{array}$ & Type of Yeast & $\begin{array}{c}\text { Content of Sugar } \\
\text { in Must from } \\
\text { Cabernet } \\
\text { Sauvignon Grapes } \\
(\mathrm{g} / \mathrm{L})\end{array}$ \\
\hline 3 & $\begin{array}{l}\text { F-8 } \\
\text { F-78 } \\
\text { D-80 }\end{array}$ & $\begin{array}{c}215.0 \pm 9.2^{\mathrm{b}} \\
195.5 \pm 8.9^{\mathrm{a}} \\
221.3 \pm 11.0^{\mathrm{b}}\end{array}$ & 3 & $\begin{array}{l}\text { F-8 } \\
\text { F-78 } \\
\text { D-80 }\end{array}$ & $\begin{array}{l}214.1 \pm 12.9^{\mathrm{b}} \\
198.6 \pm 10.8^{\mathrm{a}} \\
228.4 \pm 13.6^{\mathrm{b}}\end{array}$ \\
\hline 4 & $\begin{array}{l}\text { F-8 } \\
\text { F-78 } \\
\text { D-80 }\end{array}$ & $\begin{array}{l}204.2 \pm 10.8^{\mathrm{b}} \\
160.4 \pm 12.2^{\mathrm{a}} \\
210.9 \pm 9.7^{\mathrm{b}}\end{array}$ & 4 & $\begin{array}{l}\text { F-8 } \\
\text { F-78 } \\
\text { D-80 }\end{array}$ & $\begin{array}{l}202.5 \pm 11.8^{\mathrm{b}} \\
185.8 \pm 14.1^{\mathrm{a}} \\
211.9 \pm 12.8^{\mathrm{b}}\end{array}$ \\
\hline 5 & $\begin{array}{l}\text { F-8 } \\
\text { F-78 } \\
\text { D-80 }\end{array}$ & $\begin{array}{c}170.5 \pm 8.3^{\mathrm{b}} \\
134.8 \pm 10.1^{\mathrm{a}} \\
190.1 \pm 9.9^{\mathrm{c}}\end{array}$ & 5 & $\begin{array}{l}\text { F-8 } \\
\text { F-78 } \\
\text { D-80 }\end{array}$ & $\begin{array}{l}194.4 \pm 10.0^{\mathrm{b}} \\
179.0 \pm 12.8^{\mathrm{a}} \\
202.1 \pm 13.1^{\mathrm{b}}\end{array}$ \\
\hline 6 & $\begin{array}{c}\text { F-8 } \\
\text { F-78 } \\
\text { D-80 }\end{array}$ & $\begin{array}{c}140.7 \pm 10.8^{\mathrm{b}} \\
92.8 \pm 9.2^{\mathrm{a}} \\
174.3 \pm 12.4^{\mathrm{c}} \\
\end{array}$ & 6 & $\begin{array}{c}\text { F-8 } \\
\text { F-78 } \\
\text { D-80 }\end{array}$ & $\begin{array}{c}188.5 \pm 12.6^{\mathrm{b}} \\
164.7 \pm 13.1^{\mathrm{a}} \\
196.5 \pm 13.0^{\mathrm{b}, \mathrm{c}} \\
\end{array}$ \\
\hline 7 & $\begin{array}{l}\text { F-8 } \\
\text { F-78 } \\
\text { D-80 }\end{array}$ & $\begin{array}{c}85.5 \pm 9.5^{\mathrm{b}} \\
72.6 \pm 10.4^{\mathrm{a}} \\
99.9 \pm 7.1^{\mathrm{c}}\end{array}$ & 7 & $\begin{array}{l}\text { F-8 } \\
\text { F-78 } \\
\text { D-80 }\end{array}$ & $\begin{array}{c}183.3 \pm 12.5^{\mathrm{b}} \\
151.8 \pm 12.4^{\mathrm{a}} \\
187.6 \pm 9.8^{\mathrm{b}}\end{array}$ \\
\hline & & & 8 & $\begin{array}{c}\text { F-8 } \\
\text { F-78 } \\
\text { D-80 }\end{array}$ & $\begin{array}{c}170.3 \pm 13.0^{\mathrm{b}} \\
120.1 \pm 9.6^{\mathrm{a}} \\
176.9 \pm 12.1^{\mathrm{b}}\end{array}$ \\
\hline & & & 9 & $\begin{array}{l}\text { F-8 } \\
\text { F-78 } \\
\text { D-80 }\end{array}$ & $\begin{array}{c}151.4 \pm 13.4^{\mathrm{b}} \\
98.5 \pm 7.5^{\mathrm{a}} \\
163.8 \pm 11.5^{\mathrm{b}, \mathrm{c}}\end{array}$ \\
\hline \multicolumn{6}{|c|}{ ANOVA factors and interactions } \\
\hline \multicolumn{6}{|c|}{$p$-values } \\
\hline $\begin{array}{c}\text { Days of } \\
\text { fermentation }\end{array}$ & & 0.00 & & 0.001 & \\
\hline $\begin{array}{c}\text { Type of yeast } \\
\text { Grape Variety } \\
\text { Days of }\end{array}$ & & $\begin{array}{l}\mathbf{0 . 0 1} \\
0.12\end{array}$ & & $\begin{array}{l}\mathbf{0 . 0 2} \\
0.49\end{array}$ & \\
\hline $\begin{array}{l}\text { fermentation } x \\
\text { type of yeast } \\
\text { Days of }\end{array}$ & & 0.01 & & 0.03 & \\
\hline $\begin{array}{l}\text { fermentation } \mathrm{x} \\
\text { grape variety }\end{array}$ & & 0.14 & & 0.09 & \\
\hline $\begin{array}{l}\text { Type of yeast } x \\
\text { grape variety }\end{array}$ & & 0.32 & & 0.58 & \\
\hline
\end{tabular}

Note: Mean \pm STDV were expressed in $\%$ of two replicates and four analytical measurements. The different superscript letters $\left({ }^{a-c}\right)$ mean significant differences $(p<0.05)$ among the results in the same column in decreasing order. Faster decrease of content of sugar means higher efficiency of the yeast. Significant $p$ values $(p<0.05)$ are shown in bold. 
The results from the statistical analysis presented in Table 3 indicated that days of fermentation, type of yeast, and interaction of days of fermentation as significant factors for wines from both varieties of grapes.

\subsection{Oenochemical Parameters of Vranec and Cabernet Sauvignon Wines Produced by Autochthonous and Commercial Yeast Strains}

The results from the oenochemical parameters of Vranec and Cabernet Sauvignon wines resorting to the autochthonous yeast strains F-8 and F-78 and the commercial yeast strain D-80 for fermentation are shown in Table 4.

Table 4. Mean values and standard deviations (mean \pm STDV) of oenological parameters of wines from Vranec and Cabernet Sauvignon grape varieties and fermented by autochthonous and commercial yeast strains. Wine type abbreviations are defined in Table 1.

\begin{tabular}{|c|c|c|c|c|c|}
\hline $\begin{array}{c}\text { Wine } \\
\text { Designation }\end{array}$ & $\begin{array}{l}\text { Alcohol } \\
\% \text { (vol.) }\end{array}$ & $\begin{array}{c}\text { Total Reducing Sugars } \\
\left(\mathrm{g}_{\text {sugars }} / \mathrm{L}_{\text {wine }}\right)\end{array}$ & $\begin{array}{c}\text { Titratable Acids (TA) } \\
\left(\mathrm{g}_{\mathrm{TA}} / \mathrm{L}_{\text {wine }}\right)\end{array}$ & $\begin{array}{l}\text { Volatile Acids (VA) } \\
\quad\left(\mathrm{g}_{\mathrm{VA}} / \mathrm{L}_{\text {wine }}\right)\end{array}$ & $\mathrm{pH}$ \\
\hline V1 & $14.96 \pm 1.51^{\mathrm{a}}$ & $2.2 \pm 0.0^{\mathrm{a}}$ & $6.89 \pm 1.01^{b}$ & $0.68 \pm 0.09^{a}$ & $3.32 \pm 0.11^{b}$ \\
\hline $\mathrm{V} 2$ & $14.11 \pm 2.01^{\mathrm{a}, \mathrm{b}}$ & $2.0 \pm 0.1^{b}$ & $7.13 \pm 0.98^{a}$ & $0.43 \pm 0.07^{c}$ & $3.26 \pm 0.23^{b}$ \\
\hline V3 & $14.53 \pm 1.09^{\mathrm{a}}$ & $2.2 \pm 0.4^{\mathrm{a}}$ & $7.34 \pm 0.44^{\mathrm{a}}$ & $0.61 \pm 0.05^{\mathrm{a}}$ & $3.24 \pm 0.49^{b}$ \\
\hline CS1 & $14.51 \pm 0.98^{\mathrm{a}}$ & $2.0 \pm 0.0^{b}$ & $5.32 \pm 0.67^{c}$ & $0.42 \pm 0.01^{c}$ & $3.95 \pm 0.57^{\mathrm{a}}$ \\
\hline CS2 & $14.68 \pm 2.03^{\mathrm{a}}$ & $2.0 \pm 0.3^{b}$ & $6.29 \pm 0.81^{b}$ & $0.65 \pm 0.04^{\mathrm{a}}$ & $3.84 \pm 0.09^{a}$ \\
\hline CS3 & $13.97 \pm 1.77^{\mathrm{b}}$ & $2.2 \pm 0.7^{\mathrm{a}}$ & $5.92 \pm 0.39^{c}$ & $0.50 \pm 0.07^{b, c}$ & $3.88 \pm 0.41^{\mathrm{a}}$ \\
\hline \multicolumn{6}{|c|}{ ANOVA factors and interactions } \\
\hline$p$-values & & & & & \\
\hline Yeast strains & 0.03 & 0.04 & 0.01 & 0.01 & 0.04 \\
\hline $\begin{array}{c}\text { Grape } \\
\text { varieties }\end{array}$ & 0.42 & 0.83 & 0.02 & 0.04 & 0.85 \\
\hline $\begin{array}{c}\text { Yeast strains } \\
\text { x Grape } \\
\text { varieties }\end{array}$ & 0.72 & 0.84 & 0.43 & 0.24 & 0.09 \\
\hline
\end{tabular}

Note: Mean \pm STDV were expressed in $\mathrm{mg}_{\text {analyt }} / \mathrm{L}_{\text {wine }}$ of two replicates and four analytical measurements. The different superscript letters $\left({ }^{a-c}\right)$ mean significant differences $(p<0.05)$ among results in the same column. Significant $p$ values $(p<0.05)$ are shown in bold.

The results from Table 4 indicated a significant difference for the Cabernet Sauvignon wine CS3 (see Table 1 for wine designations) produced with commercial yeast D-80 (13.97\%). The percentage of alcohol in the other Cabernet Sauvignon wines (CS1 and CS2) and all Vranec wines (V1-V3) were above $14 \%$. The concentration of total reducing sugars in all six wines were in the range from 2.0 to $2.3 \mathrm{~g} / \mathrm{L}$. Nevertheless, the lowest amounts of titratable acids were obtained in wines from the Cabernet Sauvignon grape variety fermented by the autochthonous yeast strain (F-8) and commercial yeasts strain (D-80), chiefly 5.21 and $5.92 \mathrm{~g} / \mathrm{L}$, respectively. The lowest concentrations of volatile acids in wines from both grape varieties were observed in those fermented by autochthonous yeast strains (F-8 for Vranec and F-78 for Cabernet Sauvignon wines). Specifically, the amount of volatile acids in Vranec wine V2 fermented by autochthonous yeast strain F-78 was $0.43 \mathrm{~g} / \mathrm{L}$, whereas in wine CS1 fermented by autochthonous yeast strain F-8, it was $0.42 \mathrm{~g} / \mathrm{L}$. Overall, the $\mathrm{pH}$ values for Vranec wines produced by autochthonous and commercial yeast strains were lower in comparison to the Cabernet Sauvignon wines produced by the same yeast strains. Significant differences among parameters were confirmed by statistical analysis. The effect of yeast strain was significant for all parameters presented in Table 4, while the effect of grape variety was significant only with respect to the variables volatile compounds and titratable acids. Interaction effect between yeast strain and grape variety was not statistically significant for any of the parameters presented in Table 4.

In contrast to the oenochemical parameters summarized in Table 4, the influence of yeast strains on the content of total phenolic compounds, total anthocyanins, and color intensity was substantially more noticeable. The results presented in Table 5, unfold the highest amount of total phenolic compounds for wines of both grape varieties when the 
commercial yeast strain (D-80) was employed. On the other hand, the highest levels of anthocyanins were detected for Vranec wine V1 fermented with autochthonous yeast strain F-8 $(653.3 \mathrm{~g} / \mathrm{L})$ and Vranec wine V3 fermented with commercial yeast strain (D80) $(637.1 \mathrm{~g} / \mathrm{L})$. Moreover, the highest color intensity for Vranec wines was detected for Vranec wine V1, while Cabernet Sauvignon wines CS1 and CS3 had higher values for color intensity in comparison to the wine CS2 fermented by autochthonous yeast F-78 (please see the experimental design and abbreviations in Table 1). Statistical analysis presented in Table 5 indicates significant differences among the results for total anthocyanins for two factors and the interaction, while only the type of yeasts had a significant effect on the other two parameters namely, total phenolic compounds and color intensity. The significant interaction effect for total anthocyanins lead to the conclusion that a comparison among yeast strains can only be done by variety. In addition, the significant interaction between yeast strain and variety indicates the need to select isolated yeast to fit specific varieties. Such a profile can also be unfolded by analyzing Figure 3 .

Table 5. Mean values and standard deviations (mean \pm STDV) of total phenolic compounds, total anthocyanins, and color intensity (IC) of wines from the Vranec and Cabernet Sauvignon grape varieties and fermented by autochthonous and commercial yeast strains. Wine type abbreviations are defined in Table 1.

\begin{tabular}{|c|c|c|c|}
\hline Wine Designation & $\begin{array}{l}\text { Total Phenolic Compounds (TPC) } \\
\left(\mathrm{mg}_{\text {analyt }} / \mathrm{L}_{\text {wine }}\right)\end{array}$ & $\begin{array}{l}\text { Total Anthocyanins } \\
\left(\mathrm{mg}_{\text {analyt }} / \mathrm{L}_{\text {wine }}\right)\end{array}$ & Color Intensity (a.u.) \\
\hline V1 & $1512.7 \pm 23.55^{b}$ & $653.3 \pm 11.08^{a}$ & $31.31 \pm 4.21^{\mathrm{a}}$ \\
\hline $\mathrm{V} 2$ & $1528.9 \pm 39.01^{b}$ & $583.7 \pm 22.65^{b}$ & $21.02 \pm 5.28^{b}$ \\
\hline $\mathrm{V} 3$ & $1617.2 \pm 24.72^{a}$ & $637.1 \pm 19.87^{\mathrm{a}}$ & $23.62 \pm 3.97^{b}$ \\
\hline CS1 & $1495.9 \pm 23.55^{b, c}$ & $540.7 \pm 12.04^{\mathrm{c}}$ & $31.05 \pm 2.99^{\mathrm{a}}$ \\
\hline CS2 & $1450.5 \pm 34.21^{\mathrm{c}}$ & $472.9 \pm 20.11^{\mathrm{c}, \mathrm{d}}$ & $21.01 \pm 4.01^{b}$ \\
\hline CS3 & $1610.8 \pm 13.90^{\mathrm{a}}$ & $573.8 \pm 17.91^{\mathrm{b}}$ & $32.72 \pm 3.87^{\mathrm{a}}$ \\
\hline \multicolumn{4}{|c|}{ ANOVA factors and interactions } \\
\hline \multicolumn{4}{|l|}{$p$-values } \\
\hline Yeast strains & 0.04 & 0.01 & 0.02 \\
\hline Grape varieties & 0.03 & 0.02 & 0.14 \\
\hline Yeast strains x Grape varieties & 0.15 & 0.04 & 0.21 \\
\hline
\end{tabular}

Note: Mean \pm STDV were expressed in $\mathrm{mg}_{\text {analyt }} / \mathrm{L}_{\text {wine }}$ of two replicates and four analytical measurements. The different superscript letters $\left.{ }^{(a-d}\right)$ mean significant differences $(p<0.05)$ among results in the same column. Significant $p$ values $(p<0.05)$ are shown in bold.

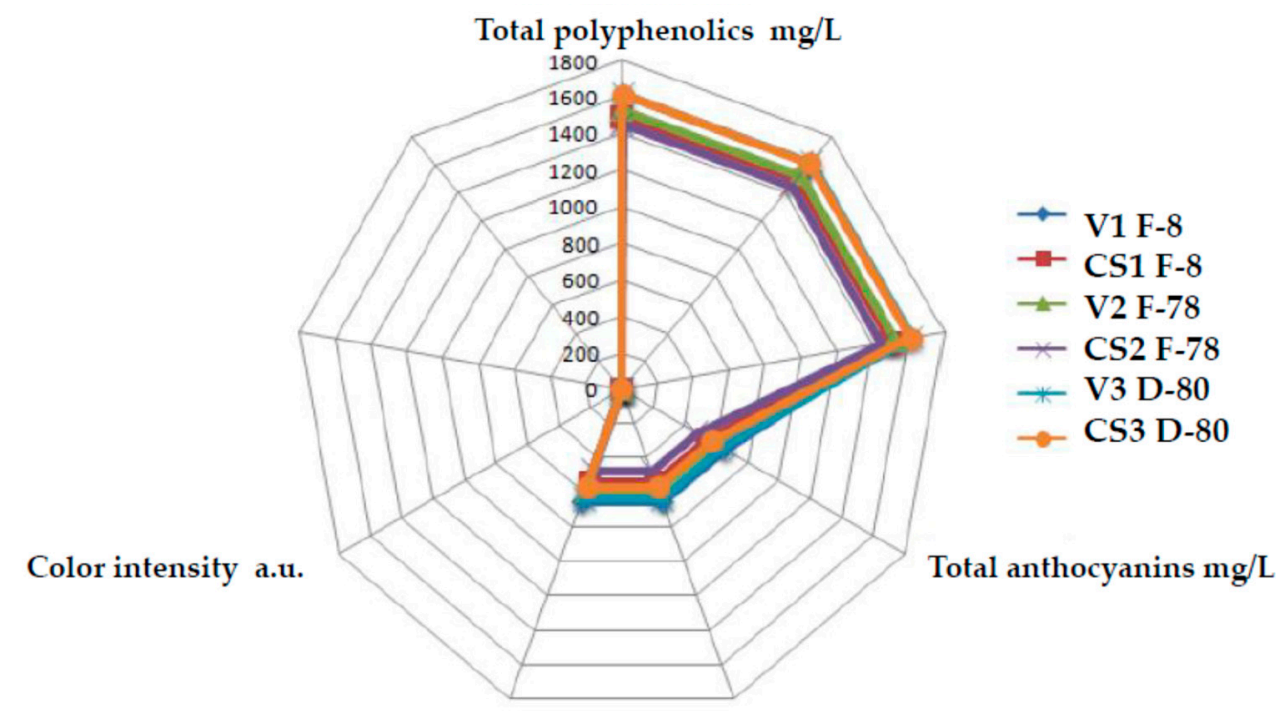

Figure 3. Mean values and standard deviations (mean $\pm \mathrm{STDV}$ ) of total phenolic content $\left(\mathrm{mg}_{\text {analyt }} / \mathrm{L}_{\text {wine }}\right.$ ), total anthocyanins ( $\mathrm{mg}_{\text {analyt }} / \mathrm{L}_{\text {wine }}$ ) and color intensity (a.u.) of wines from Vranec and Cabernet Sauvignon grape varieties and fermented by autochthonous and commercial yeast strains. Mean \pm STDV were calculated from two replicates of each fermentation type (see Table 1) and four analytical measurements. Wine type abbreviations are defined in Table 1. 
According to Figure 3, the results in this current research effort revealed a significant influence of type of yeast strains employed during the fermentation in the oenochemical parameters as well as in the content of polyphenolic compounds, total anthocyanins, and color intensity of the produced wines. Besides, the influence of the type of yeast strain during winemaking depends significantly on the grape varieties. In other words, the influence of the same autochthonous and commercial yeast strains in the final wines (under the same processing conditions) depends significantly on the type of wine grape (viz. Vranec and Cabernet Sauvignon varieties).

\section{Discussion}

Although the autochthonous (F-8 and F-78) and commercial (D-80) yeast strains belong to the same species of Saccharomyces cerevisiae, the dynamics of alcoholic fermentation presented in Figures 1 and 2 and Table 3 confirm the findings of Barrajón et al. where autochthonous yeast strains had the ability for better adaptation in grape must in comparison to the commercial yeast strains. According to the findings of Barrajón et al. (2011) [26], when commercial and wild strains were inoculated at the same rate, the wild strains were dominant not only in the fermentation in the cellar, but also in the laboratory assays. In addition, the wild strains, when reaching $50 \%$ of composition in the vinification vat, improved their performance under controlled conditions [26]. In fact, autochthonous strains in distinct matrixes often show higher functional and technological performance than allochthonous strains due to its inherent better adaptability to the original raw materials, which justifies the microbial prospection toward their potential use in food processing systems.

In addition, dynamics of alcoholic fermentation depends on the presence of tannins and fermentation activators. Such a correlation was observed in the present studies when it was observed that the same yeast fermentation under the same winemaking conditions resulted in distinct profiles of fermentation curves (i.e., the same yeast fermentation under the same winemaking conditions resulted in different shapes of fermentation curves (Figures 1 and 2)). According to the findings of Ríos et al. (2014) [27], the fermentation activity of individual yeast strains depends of abiotic factors $(\mathrm{pH}$, temperature, ethanol, osmotic pressure, nitrogen, etc.) and simultaneously in biotic factors (microorganisms, killer factors, grape variety, etc.). Moreover, there is a trend to imply co-inoculation with different yeast strains (i.e., the use of consortia of yeast strains) in order to reach improved characteristics of wines and achieved organoleptic complexity [27].

As noted, in Vranec wines, substantial changes in the shape of the curves was evident from the 3rd to 7th days of fermentation, while in Cabernet Sauvignon wines, it occurred from the 3rd to 9th days fermentation (Figures 1 and 2 and Table 3 ) in favor of autochthonous yeast strain F-78. According to Vigentini et al. (2014) [28], the evolution of yeast populations during controlled fermentation of Chardonnay musts in two Italian wineries depended on the presence of autochthonous yeast strains. Specifically, in the first winery, where the oenologist carefully managed only one of three starter cultures and did not carry out any spontaneous fermentation, the commercial yeast strain always mastered the process; conversely, in the second winery, where the oenologist simultaneously performed spontaneous fermentation, the yeast starter culture did never take over the microbial growth dominance (despite staying viable over the fermentation) and a continuous succession of distinct autochthonous Saccharomyces cerevisiae, Pichia membranifaciens, and Hanseniaspora vinae strains dominated the fermentation without one never prevailed on the other autochthonous strains [29]. Furthermore, sensitivity/vulnerability of yeast strains to ethanol toxicity is also a very well-known condition, which can affect the microbial dynamics of fermentations, since the ethanol inhibits sugar metabolic pathways of the yeasts. The tolerance of yeast strains to the toxicity of ethanol is strongly dependent on the temperature and leads to the conclusion that some yeast strains have more aptitude to finish fermentations under lower temperatures [30-32]. 
Results displayed in the current research (Table 4) showed that the influence of yeast strains is better and more intensively expressed based on the total phenolic content of wines in comparison to the oenochemical parameters. Generally, higher amounts of total phenolic compounds and total anthocyanins in wines produced with both grape varieties was observed when the autochthonous yeast strain F-8 and the commercial yeast strain D-80 were used (Table 5). In fact, the microbial dynamics of specific yeast population under controlled fermentation inevitably results in specific organoleptic and sensory characteristics of the final wines, and such microbial dynamics are dependent on the grape variety $[33,34]$. Bitterness and astringency of the produced wines depends on the amount of anthocyanins in grape skin and tannins in grape seeds [35].

The data in this work (Table 5 and Figure 3) showed that grapes from the Vranec variety had a higher amount of anthocyanins in the skins in comparison to the Cabernet Sauvignon grapes. This explains the higher amount of total anthocyanins found in all Vranec wines when compared to the wines from the Cabernet Sauvignon grapes, both of which were produced under the same winemaking conditions. However, the highest amount of total phenolic compounds (Figure 3) in wines from both grape varieties were obtained when the fermentation was undertaken by the commercial yeast strain D- 80 . The commercial yeast strain D-80 isolated from the Côte Rôtie area of the Rhône Valley is claimed to have advantageous phenotype characteristics to ferment polyphenol-rich red musts and it is one of the preferred strains for contributing to the high tannin content (Lallemand Oenology Inc., Vienna, Austria) [36]. The importance of tannins derives from its contribution to the organoleptic characteristics such as astringency [37]. In general, tannin activity is primarily driven by its molecular size. In fact, based on the different maceration times applied, many studies have revealed that increases in the perceived astringency quality are related to the tannin chemistry (i.e., it is driven by tannin molecular mass), as opposed to the tannin pigmentation formation or oxidation effect [34]. Moreover, inter- and intramolecular co-pigmentation of anthocyanins and colorless co-pigments can significantly change the overall color and intensity of red wines [38]. Results from our study confirmed such conclusions. Although Vranec wines V1 and V3 contained the highest amount of total anthocyanins (Table 5), the intensity of the color was remarkable for Cabernet Sauvignon wines CS1 and CS3. The anthocyanin composition in red wines depends not only on the original anthocyanin profile in grape berries, but also on the enological techniques applied [39]. The yeast behavior can modify the phenolic content of red wines by their ability to absorb the phenolic compounds on the yeast cell walls [40]. Moreover, absorption of the phenolic compounds on the yeast cell during fermentation can result in the loss of wine color [41,42]. Results from our study (Figure 3) indicated that the highest value for color intensity of Vranec wines V1 and V3 fermented by yeast strains F-8 and D-80, respectively, as well as the Cabernet Sauvignon wine CS3 fermented by yeast strain D-80. Such a behavior led us to show that isolated autochthonous yeast strains do not always meet all the desired phenotype traits for winemaking but, important to mention, they contribute effectively to the biodiversity and microbial heritage, which can be very useful to develop and improve new and successful fermentation processes toward the innovation, diversity, and authenticity of wines [43-46]. The existence of yeast strains with superior genetic traits and technological potential can be achieved through the exploitation of the variety of grape and optimization of the fermentation conditions. Thus, the continuous microbial prospection of yeast strains in natural sources (grapes) from different varieties and from different geographical regions is essential in such a direction. These findings make it clear that the use of mixed starter cultures (i.e., consortia of autochthonous (and eventually with commercial) yeast strains) can become a promising approach to be explored through food engineering. Accordingly, and as observed in Table 5, although autochthonous yeast strain F-78 selected from thee Tkiveš wine-growing region was superior for the fermentation of Vranec wines, changes in fermentation conditions can become more favorable to the autochthonous F- 8 or to the commercial D- 80 yeast strains [47-49]. Comparison of results from our study (Figure 3) with those obtained by 
Ilieva et al. $(2016,2017)[17,18]$ unequivocally showed that fermentation of wines from the same grape varieties, but from different winemaking locations and different vintage years, and from the same yeast strains have different behaviors [17,18]. This is linked to the finding that the presence of different yeasts during fermentation, especially wineryspecific strains, contributes to an increase in the wine complexity and differentiation [50]. Moreover, the fact that wines were produced in different vineries, led us to conclude that autochthonous $S$. cerevisiae strains occurring at higher percentages in spontaneous alcoholic fermentations are more competitive, possibly because of their higher adaptability to the natural matrix as well as to the progressive changes in environmental conditions throughout fermentation, particularly the ethanol content and temperature [51]. Indeed, some predominant $S$. cerevisiae strains persisted in different fermentations in the same winery from one year to another and they seem to be representative of a single winery rather than of an oenological geographical area [52-56].

\section{Conclusions}

In this research study, six wines were produced using the factorial design constituted by the type of yeast (two autochthonous and one commercial yeast) and two varieties of wine grapes (Table 1). All combinations of the factors were tested and the fermentation conditions remained the same in all produced wines. The wines from the Vranec grape variety exhibited a high amount of anthocyanins, which is related to grape variety, but the overall color intensity was not significantly different in comparison to the wines produced with the Cabernet Sauvignon grape variety. The total phenolic content of wines produced with the Cabernet Sauvignon grape variety displayed lower values when compared with the Vranec wines. The dynamics of alcoholic fermentation in Vranec wines (from the third to seventh days) fermented by the autochthonous yeast strain F-78 showed a sharper decrease in total reducing sugar content. Changes in color intensity is likely to be caused by the individual ability of yeast strains to absorb the anthocyanins and other phenolic compounds throughout the fermentation process as well as co-pigmentation during winemaking.

Author Contributions: Individual contributions from authors were as follows: Conceptualization, F.I., K.P., S.K.V., and T.E.; Methodology, F.I., K.P., S.K.V., and T.E.; Software, S.K.V., and T.E.; Validation, S.K.V., N.G., J.M.F.R., and T.E.; Formal analysis, F.I., K.P., S.K.V., N.G., V.D., J.M.F.R., and T.E.; Investigation, F.I., K.P., S.K.V., N.G., V.D., and T.E.; Resources, F.I., K.P., S.K.V., N.G., and T.E.; Data curation, F.I., K.P., S.K.V., N.G., V.D., and T.E.; Writing-original draft preparation, F.I., K.P., S.K.V., N.G., V.D., and T.E.; Writing—review and editing, F.I., K.P., S.K.V., N.G., V.D., J.M.F.R., and T.E.; Visualization, F.I., K.P., S.K.V., N.G., V.D., J.M.F.R., and T.E.; Supervision F.I., K.P., S.K.V., N.G., V.D., and T.E.; Project administration, F.I., K.P., S.K.V., and T.E.; Funding acquisition, F.I., K.P., S.K.V., and T.E. All authors have read and agreed to the published version of the manuscript.

Funding: The publication of this article was funded by the Open Access Fund of the Leibniz Universität Hannover, Germany.

Institutional Review Board Statement: Not applicable.

Informed Consent Statement: Not applicable.

Data Availability Statement: All experimental data to support the findings of this study are available contacting the corresponding author upon request.

Acknowledgments: This work is based upon the Master of Science of one of the authors Kire Petrov (K.P.) (North Macedonia). The authors acknowledge Tikveš Winery and the Faculty of Agriculture, University "Goce Delčev"-Štip for the conditions for the development of the research work. The authors also wish to acknowledge Leibniz Universität Hannover, Germany, for the financial support to publish this manuscript in the open access journal Microorganisms. The local farmers from the Tikveš wine-growing region are hereby gratefully acknowledged by the authors for supplying samples of grapes for analyses. This work is also based upon the work from COST Action 18101 SOURDOMICS-Sourdough biotechnology network towards novel, healthier and sustainable food and bioprocesses (https://sourdomics.com/; https:/ /www.cost.eu/actions/CA18101/), where the author J.M.R. is the Chair and Grant Holder Scientific Representative; T.E. is a management committee 
member from Germany; and S.K.V. is a MC (substitute) member from North Macedonia and is supported by COST (European Cooperation in Science and Technology) (https:/ /www.cost.eu/). COST is a funding agency for research and innovation networks.

Conflicts of Interest: The authors declare no conflict of interest.

\section{References}

1. Cadière, A.; Aguera, E.; Caillé, S.; Ortiz-Julien, A.; Dequin, S. Pilot-scale evaluation the enological traits of a novel, aromatic wine yeast strain obtained by adaptive evolution. Food Microbiol. 2012, 32, 332-337. [CrossRef]

2. Berbegal de Gracia, C.; Garofalo, C.; Russo, P.; Pati, S.; Capozzi, V.; Spano, G. Use of Autochthonous yeasts and bacteria in order to control Brettanomyces bruxellensis in wine. Fermentation 2017, 3, 1-11.

3. Zabukovec, P.; Čadež, N.; Čuš, F. Isolation and Identification of indigenous wine yeasts and their use in alcoholic fermentation. Food Technol. Biotechnol. 2020, 58, 337-347. [CrossRef]

4. Raymond Eder, M.L.; Conti, F.; Rosa, A.L. Differences between indigenous yeast populations in spontaneously fermenting musts from $V$. vinifera L. and $V$. labrusca L. grapes harvested in the same geographic location. Front. Microbiol. 2018, 9, 1320. [CrossRef]

5. Brossaud, F.; Cheynier, V.; Noble, A. Bitterness and astringency of grape and wine polyphenols. Aust. J. Grape Wine Res. 2001, 7, 33-39. [CrossRef]

6. Nel, A.P.; Van Rensburg, P.; Lambrechts, M.G. The influence of different winemaking techniques on the extraction of grape tannins and anthocyanins. S. Afr. J. Enol. Vitic. 2014, 35, 304-320. [CrossRef]

7. Watrelot, A.A.; Norton, E.L. Chemistry and reactivity of tannins in Vitis spp.: A review. Molecules 2020, 25, 2110. [CrossRef]

8. Yacco, R.S.; Watrelot, A.A.; Kennedy, J.A. Red wine tannin structure-Activity relationships during fermentation and maceration. J. Agric. Food Chem. 2016, 64, 860-869. [CrossRef]

9. García-Estévez, I.; Cristina Alcalde-Eon, C.; Víctor Puente, V.; Escribano-Bailón, T.M. Enological tannin effect on red wine color and pigment composition and relevance of the yeast fermentation products. Molecules 2017, 22, 2046. [CrossRef]

10. Smith, P.A.; McRae, J.M.; Bindon, K.A. Impact of winemaking practices on the concentration and composition of tannins in red wine. Aust. J. Grape Wine Res. 2015, 21, 601-614. [CrossRef]

11. Pereira de Freitas, V.A.; Fernandes, A.; Oliveira, J.; Teixeira, N.; Mateus, N. A review of the current knowledge of red wine colour. OENO One 2017, 51. [CrossRef]

12. De Freitas, V.; Mateus, N. Formation of pyranoanthocyanins in red wines: A new and diverse class of anthocyanin derivatives. Anal. Bioanal. Chem. 2010, 401, 1463-1473. [CrossRef]

13. He, F.; Liang, N.N.; Mu, L.; Pan, Q.H.; Wang, J.; Reeves, M.J.; Duan, C.Q. Anthocyanins and their variation in red wines I. monomeric anthocyanins and their color expression. Molecules 2012, 17, 1571-1601. [CrossRef]

14. Kostadinović Veličkovska, S.; Mirhosseini, H.; Bogeva, E. Isolation of anthocyanins by high-speed countercurrent chromatography and application of the color activity concept to different varieties of red grape pomace from Macedonia. J. Nutr. Food. Sci. 2013, 3, 243-250.

15. OIV-AS2-02-SUCREF Compendium of International Methods of Analysis of Wines and Musts; International Organization of Vine and Wine: Paris, France, 2007; Volume 2.

16. OIV-AS-313-01-ACITOT Compendium of International Methods of Analysis of Wines and Musts; International Organization of Vine and Wine: Paris, France, 2009; Volume 2.

17. Ilieva, F.; Kostadinović Veličkovska, S.; Dimovska, V.; Spasov, H. The impact of some wine-making practices on the quality of Vranec red wines from Macedonia produced by the newly-selected local strain "F-78". Food Chem. 2016, 194, 1123-1131. [CrossRef] [PubMed]

18. Ilieva, F.; Kostadinović Veličkovska, S.; Dimovska, V.; Mirhosseini, H.; Spasov, H. Selection of 80 newly isolated autochthonous yeast strains from the Tikveš region of Macedonia and their impact on the quality of red wines produced from Vranec and Cabernet Sauvignon grape varieties. Food Chem. 2017, 216, 309-315. [CrossRef]

19. Ilieva, F.; Kostadinović Veličkovska, S.; Dimovska, V.; Mirhosseini, H.; Spasov, H. Isolation of Saccharomyces cerevisiae yeast strains from Macedonian "Tikveš" wine-growing region and their impact on the organoleptic characteristics of Vranec and Cabernet Sauvignon wines. Res. J. Biotechnol. 2019, 14, 100-110.

20. Bambalov, G.; Spasov, C.; Bambalov, K. Isuliorung und selection von Weinhefen aus dem Westtilchen teil der Thrazischeen tiefeben. Wein Wiss. 2000, 55, 55-57.

21. Zoecklein, B.W.; Gugelsang, K.C.; Gump, B.H.; Nury, F.S. Wine Analysis and Production; Chapman and Hall: New York, NY, USA, 2000.

22. ISI 28-1e Determination of Reducing Sugar, DE by Luff-Schoorl's Method. Available online: http://www.starch.dk/isi/methods / 28luff.htm (accessed on 1 January 2018).

23. AOAC. Official Method 2005.02 Total Monomeric Anthocyanin Pigment Content of Fruit Juices, Beverages, Natural Colorants, and Winesand. J. AOAC Int. 2005, 88, 1269.

24. AOAC SMPR 2015.009: Estimation of Total Phenolic Content Using the Folin-C Assay; AOAC International: Rockville, MD, USA, 2015.

25. OIV-MA-AS313-01 Compendium of International Methods of Analysis of Wines and Musts. R; International Organization of Vine and Wine: Paris, France, 2015; Volume 2. 
26. Barrajón, N.; Arévalo-Villena, M.; Úbeda, J.; Briones, A. Enological properties in wild and commercial Saccharomyces cerevisiae yeasts: Relationship with competition during alcoholic fermentation. World J. Microbiol. Biotechnol. 2011, 27, 2703-2710. [CrossRef]

27. García-Ríos, E.; Gutiérrez, A.; Salvadó, Z.; Arroyo-López, F.N.; Guillamon, M. The fitness advantage of commercial wine yeasts in relation to the nitrogen concentration, temperature, and ethanol content under microvinification conditions. Appl. Environ. Microbiol. 2014, 80, 704-713. [CrossRef]

28. Vigentini, I.; Fabrizio, V.; Faccincani, M.; Picozzi, C.; Comasio, A.; Foschino, R. Dynamics of Saccharomyces cerevisiae populations in controlled and spontaneous fermentations for Franciacorta D.O.C.G. base wine production. Ann. Microbiol. 2014, 64, 639-651. [CrossRef]

29. Gao, C.; Fleet, G.H. The effects of temperature and $\mathrm{pH}$ on the ethanol tolerance of the wine yeasts, Saccharomyces cerevisiae, Candida stellata and Kloeckera apiculata. J. Appl. Bacteriol. 1988, 65, 405-410. [CrossRef]

30. Torija, M.J.; Rozès, N.; Poblet, M.; Guillamón, J.M.; Mas, A. Effects of fermentation temperature on the strain population of Saccharomyces cerevisiae. Int. J. Food Microbiol. 2003, 80, 47-53. [CrossRef]

31. Ciani, M.; Capece, A.; Comitini, F.; Canonico, L.; Siesto, G.; Romano, P. Yeast interactions in inoculated wine fermentation. Front. Microbiol. 2016, 7. [CrossRef]

32. Caridi, A.; Cufari, A.; Lovino, R.; Palumbo, R.; Tedesco, I. Influence of yeast on polyphenol composition of wine. Food Technol. Biotechnol. 2004, 42, 37-40.

33. Tofalo, R.; Patrignani, F.; Lanciotti, R.; Perpetuini, G.; Schirone, M.; Di Gianvito, P.; Pizzoni, D.; Arfelli, G.; Suzzi, G. Aroma profile of Montepulciano d'abruzzo wine fermented by single and co-culture starters of autochthonous Saccharomyces and non-Saccharomyces yeasts. Front. Microbiol. 2016, 7, 1-12. [CrossRef] [PubMed]

34. Petruzzi, L.; Capozzi, V.; Berbegal, C.; Corbo, M.R.; Bevilacqua, A.; Spano, G.; Sinigaglia, M. Microbial resources and enological significance: Opportunities and benefits. Front. Microbiol. 2017, 8, 1-13. [CrossRef]

35. Perpetuini, G.; Tittarelli, F.; Battistelli, N.; Suzzi, G.; Tofalo, R. Contribution of Pichiamanshurica strains to aroma profile of organic wines. Eur. Food Res. Technol. 2020, 246, 1405-1417. [CrossRef]

36. Lallemand Oenology Inc., Vienna. Available online: https://www.lallemandwine.com/en/china/ (accessed on 25 April 2019).

37. Morata, A.; Gómez-Cordovés, M.C.; Colomo, B.; Suárez, J.A. Cell wall anthocyanin adsorption by different Saccharomyces strains during the fermentation of Vitis vinifera L. cv Graciano grapes. Eur. Food Res. Technol. 2005, 220, 341-346. [CrossRef]

38. Stockley, C.S.; Høj, P.B. Better wine for better health: Factor fiction? Aust. J. Grape Wine Res. 2005, 11, 127-138. [CrossRef]

39. Caridi, A.; Sidari, R.; Giuffrè, A.M.; Pellicanò, T.M.; Sicari, V.; Zappia, C.; Poiana, M. Test of four generations of Saccharomyces cerevisiae concerning their effect on antioxidant phenolic compounds in wine. Eur. Food Res. Technol. 2017, 243, 1287-1294. [CrossRef]

40. Mazauric, J.P.; Salmon, J.M. Interactions between yeast lees and wine polyphenols during simulation of wine aging: I. Analysis of remnant polyphenolic compounds in the resulting wines. J. Agric. Food Chem. 2005, 53, 5647-5653. [CrossRef]

41. Medina, K.; Boido, E.; Dellacassa, E.; Carrau, F. Yeast interactions with anthocyanins during red wine fermentation. Am. J. Enol. Vitic. 2005, 56, 104-109.

42. Kostadinović, S.; Wilkens, A.; Stefova, M.; Ivanova, V.; Vojnoski, B.; Mirhosseini, H.; Winterhalter, P. Stilbene levels and antioxidant activity of Vranec and Merlot wines from Macedonia: Effect of variety and enological practices. Food Chem. 2012, 135, 3003-3009. [CrossRef] [PubMed]

43. Giudici, P.; Solieri, L.; Pulvirenti, A.M.; Cassanelli, S. Strategies and perspectives for genetic improvement of wine yeasts. Appl. Microbiol. Biotechnol. 2005, 66, 622-628. [CrossRef]

44. De Vero, L.; Bonciani, T.; Verspohl, A.; Mezzetti, F.; Giudici, P. High-glutathione producing yeasts obtained by genetic improvement strategies: A focus on adaptive evolution approaches for novel wine strains. AIMS Microbiol. 2017, 3, 155-170. [CrossRef]

45. Mezzetti, F.; Fay, J.C.; Giudici, P.; De Vero, L. Genetic variation and expression changes associated with molybdate resistance from a glutathione producing wine strain of Saccharomyces cerevisiae. PLoS ONE 2017, 12, 1-22. [CrossRef] [PubMed]

46. Pulvirenti, A.; De Vero, L.; Blaiotta, G.; Sidari, R.; Iosca, G.; Gullo, M.; Caridi, A. Selection of wine Saccharomyces cerevisiae strains and their screening for the adsorption activity of pigments, phenolics and ochratoxin A. Fermentation 2020, 6, 80. [CrossRef]

47. Bisson, L.F. Geographic origin and diversity of wine strains of Saccharomyces. Am. J. Enol. Vitic. 2012, 63, 165-175. [CrossRef]

48. Combina, M.; Elía, A.; Mercado, L.; Catania, C.; Ganga, A.; Martinez, C. Dynamics of indigenous yeast populations during spontaneous fermentation of wines from Mendoza, Argentina. Int. J. Food Microbiol. 2005, 99, 237-243. [CrossRef]

49. Capece, A.; Romaniello, R.; Siesto, G.; Romano, P. Diversity of Saccharomyces cerevisiae yeasts associated to spontaneously fermenting grapes from an Italian "heroic vine-growing area". Food Microbiol. 2012, 31, 159-166. [CrossRef]

50. Versavaud, A.; Courcoux, P.; Roulland, C.; Dulau, L.; Hallet, J.N. Genetic diversity and geographical distribution of wild Saccharomyces cerevisiae strains from the wine-producing area of Charentes, France. Appl. Environ. Microbiol. 1995, 61, 3521-3529. [CrossRef] [PubMed]

51. Ganucci, D.; Guerrini, S.; Mangani, S.; Vincenzini, M.; Granchi, L. Quantifying the effects of ethanol and temperature on the fitness advantage of predominant Saccharomyces cerevisiae strains occurring in spontaneous wine fermentations. Front. Microbiol. 2018, 9. [CrossRef]

52. Vezinhet, F.; Hallet, J.N.; Valade, M.; Poulard, A. Ecological survey of wine strains by molecular methods of identification. Am. J. Enol. Vitic. 1992, 43, 83-86. 
53. Sabate, J.; Cano, J.; Querol, A.; Guillamon, J.M. Diversity of Saccharomyces strains in wine fermentations: Analysis for two consecutive years. Lett. Appl. Microbiol. 1998, 26, 452-455. [CrossRef] [PubMed]

54. Granchi, L.; Ganucci, D.; Viti, C.; Giovannetti, L.; Vincenzini, M. Saccharomyces cerevisiae biodiversity in spontaneous commercial fermentations of grape musts with adequate and inadequate assimilable-nitrogen content. Lett. Appl. Microbiol. 2003, 36, 54-58. [CrossRef] [PubMed]

55. Granchi, L.; Ganucci, D.; Buscioni, G.; Mangani, S.; Guerrini, S. The Biodiversity of Saccharomyces cerevisiae in spontaneous wine fermentation: The occurrence and persistence of winery-strains. Fermentation 2019, 5, 86. [CrossRef]

56. Pérez-Caballero, V.; Ayala, F.; Echávarri, J.R.; Negueruela, A.I. Proposal for a new standard OIV method for determination of chromatic characteristics of wine. Am. J. Enol. Vitic. 2003, 54, 59-62. 